Marquette University

e-Publications@Marquette

$5-1-2008$

Formation of Bicyclic Pyrroles from the Catalytic Coupling Reaction of 2,5-disubstituted Pyrroles with Terminal Alkynes, Involving the Activation of Multiple C-H bonds

Chase S. Yi

Marquette University, chae.yi@marquette.edu

Jie Zhang

Marquette University

Accepted version. Chemical Communications, Vol. 20 (May 2008): 2349-2351. DOI. (C) 2008 Royal Society of Chemistry. Used with permission. 


\title{
Formation Of Bicyclic Pyrroles From The Catalytic Coupling Reaction Of 2,5-Disubstituted Pyrroles With Terminal Alkynes, Involving The Activation Of Multiple $\mathrm{C}-\mathrm{H}$ Bonds ${ }^{+}$
}

\author{
Chae S. Yi \\ Department of Chemistry, Marquette University \\ Milwaukee, WI \\ Jie Zhang \\ Department of Chemistry, Marquette University \\ Milwaukee, WI
}

Abstract: Substituted bicyclic pyrroles are produced directly from the coupling reaction of 2,5-disubstituted pyrroles with terminal alkynes, involving the activation of multiple $\mathrm{C}-\mathrm{H}$ bonds and regioselective cyclisation.

Transition metal-catalysed $\mathrm{C}-\mathrm{H}$ bond activation and functionalisation reactions of nitrogen heterocyclic compounds have attracted considerable attention, in part due to their prominent role in the synthesis of natural products and pharmaceutical agents. ${ }^{1}$ Highly regioselective catalytic $\mathrm{C}-\mathrm{H}$ bond insertion reactions of nitrogencontaining aromatic compounds, such as pyridines, indoles and pyrroles, have been reported in recent years. ${ }^{2}$ Direct oxidative coupling reactions of arene $\mathrm{C}-\mathrm{H}$ bonds ${ }^{3}$ and the $\mathrm{C}-\mathrm{H}$ bond oxidative 
annulation of indoles ${ }^{4}$ have also been achieved using $\mathrm{Cu}$ and $\mathrm{Pd}$ catalysts. Despite such remarkable progress, however, catalytic $\mathrm{C}-\mathrm{H}$ bond activation methods have rarely been employed for constructing nitrogen-containing heterocyclic compounds. We recently developed a new catalytic coupling reaction between arylamines and alkynes, which involved the regioselective activation of $\mathrm{sp}^{2} \mathrm{C}-\mathrm{H}$ bonds to yield tricyclic quinoline products. ${ }^{5}$ In an effort to extend the scope of catalytic $\mathrm{C}-\mathrm{H}$ bond activation reactions, we have begun to explore the coupling reactions of pyrroles and indoles. This report delineates the coupling reaction between 2,5-disubstituted pyrroles and terminal alkynes, which involves multiple $\mathrm{C}-\mathrm{H}$ bond activation and cyclisation steps.

Treatment of 2,5-dimethylpyrrole $(1.0 \mathrm{mmol})$ with 4ethynylanisole $(2.0 \mathrm{mmol})$ in the presence of $\mathrm{Ru}_{3}(\mathrm{CO})_{12} / \mathrm{NH}_{4} \mathrm{PF}_{6}$ (1: 3, $10 \mathrm{~mol} \% \mathrm{Ru})$ in benzene $(5 \mathrm{~mL})$ at $95^{\circ} \mathrm{C}$ for $36 \mathrm{~h}$ cleanly produced the cyclisation product, 1a (eqn (1)). Since 1a was found to be air sensitive, the analytically pure product was isolated by column chromatography under a nitrogen atmosphere ( $87 \%$ yield), and was fully characterised by both spectroscopic methods and elemental analysis. ${ }^{\ddagger}$ The initial catalyst activity survey showed that both $\mathrm{Ru}_{3}(\mathrm{CO})_{12}$ and $\mathrm{NH}_{4} \mathrm{PF}_{6}$ were essential for catalytic activity. Other neutral and cationic ruthenium compounds, such as $\mathrm{RuCl}_{3} \cdot 3 \mathrm{H}_{2} \mathrm{O}$, $\left(\mathrm{PPh}_{3}\right)_{3} \mathrm{RuHCl},\left(\mathrm{PCy}_{3}\right)_{2}(\mathrm{CO}) \mathrm{RuHCl}$ and $\left[\left(\mathrm{PCy}_{3}\right)_{2}(\mathrm{CO})(\mathrm{MeCN})_{2} \mathrm{RuH}^{+} \mathrm{BF}_{4}{ }^{-}\right.$, did not give any coupling products under similar reaction conditions. The analogous reaction of $\mathrm{N}$-phenylpyrrole with 4-ethynylanisole produced a mixture of $1: 1$ and 1: 2 coupling products, without forming any cyclisation product. 

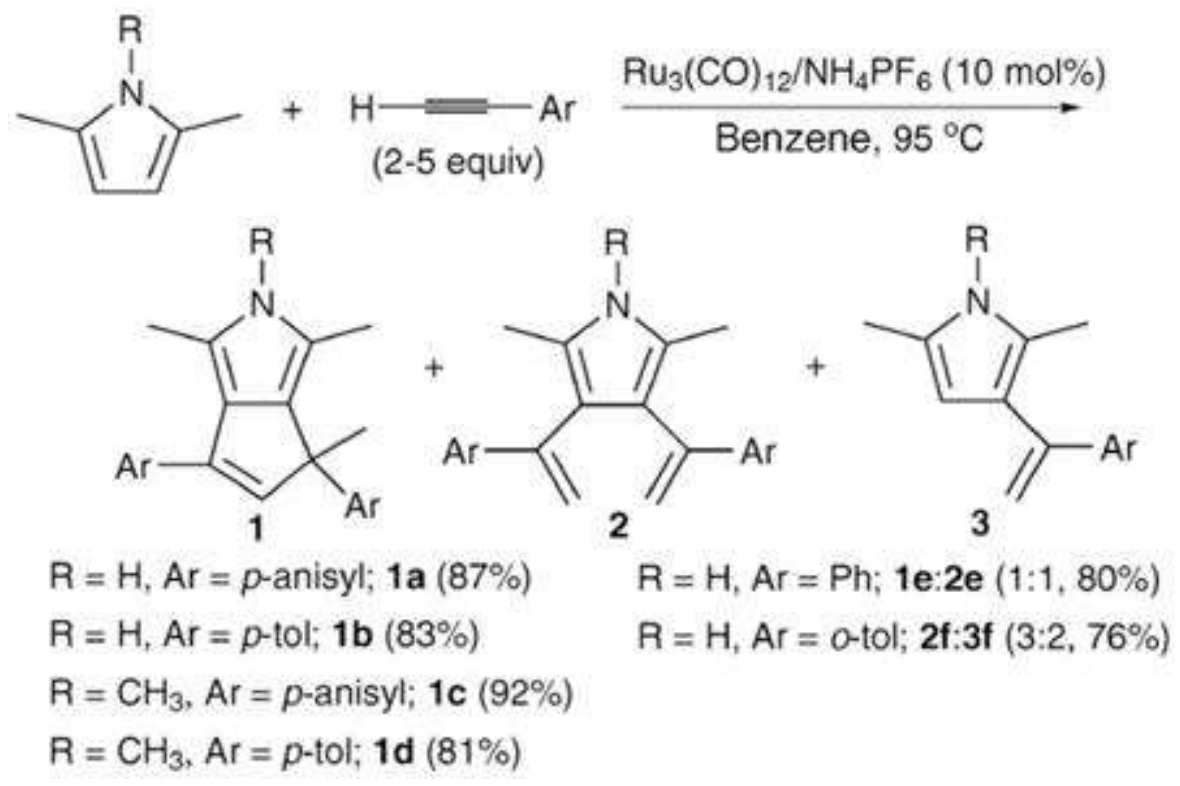

The coupling reaction was found to be strongly influenced by the steric and electronic nature of alkynes. In contrast to terminal alkynes with a para-electron-donating group, such as 4-ethynylanisole or 4ethynyltoluene, which readily produced the cyclisation products $\mathbf{1 a -}$ 1d, the coupling reaction with phenylacetylene gave a 1: 1 mixture of the cyclisation and 1: 2 insertion products, $\mathbf{1 e}$ and $\mathbf{2 e}$. The coupling reaction with sterically demanding 2 -ethynyltoluene ( 2 equiv.) produced a 3: 2 mixture of the coupling products $\mathbf{2} \mathbf{f}$ and $\mathbf{3 f}$ under similar conditions. Neither arylalkynes with an electron-withdrawing group, such as 4-ethynyltrifluorotoluene or 4-fluorophenylacetylene, nor the aliphatic terminal alkynes, gave any coupling products under similar conditions. A prolonged reaction time at a higher temperature did not convert $\mathbf{2}$ or $\mathbf{3}$ into cyclisation product $\mathbf{1}$. Instead, the cyclotrimerisation products from the homocoupling of the terminal alkynes were produced predominantly in these cases.

Since $\mathrm{Ru}_{3}(\mathrm{CO})_{12} / \mathrm{NH}_{4} \mathrm{PF}_{6}$ was not particularly effective for the coupling reactions with electron-poor arylalkynes, we next surveyed the efficacy of gold catalysts to promote the formation of cyclisation products. When 2,5-dimethylpyrrole was treated with phenylacetylene ( 2 equiv.) in the presence of $5 \mathrm{~mol} \%$ of $\mathrm{Au}\left(\mathrm{PPh}_{3}\right) \mathrm{Cl} / \mathrm{AgOTf}(1: 1)$ in benzene for $24 \mathrm{~h}, \mathbf{1 e}$ was formed exclusively, though the catalyst lost its activity after $60 \%$ conversion. Control experiments indicated that 
both $\mathrm{Au}\left(\mathrm{PPh}_{3}\right) \mathrm{Cl}$ and $\mathrm{AgOTf}$ were required for catalytic activity, and other selected gold compounds, such as $\mathrm{AuCl}_{3}$ and $\mathrm{NaAuCl}_{4}$, failed to catalyse the coupling reaction. When the $\mathrm{Au}\left(\mathrm{PPh}_{3}\right) \mathrm{Cl} / \mathrm{AgOTf}(5 \mathrm{~mol} \%)$ catalyst was treated with a 1: 1 mixture of $\mathbf{1 e}$ and $\mathbf{2 e}, \mathbf{2 e}$ was cleanly converted to $\mathbf{1 e}$ to produce an 8: 1 mixture of $\mathbf{1 e}$ and $\mathbf{2 e}$ after $10 \mathrm{~h}$ at $95^{\circ} \mathrm{C}$. By using the combined catalytic system, $\mathrm{Ru}_{3}(\mathrm{CO})_{12} / \mathrm{NH}_{4} \mathrm{PF}_{6}$ and $\mathrm{Au}\left(\mathrm{PPh}_{3}\right) \mathrm{Cl} / \mathrm{AgOTf}$, cyclisation product 1e was obtained from the coupling reaction of 2,5-dimethylpyrrole with phenylacetylene ( $>95 \%$ conversion, $81 \%$ combined yield, $\mathbf{1 e :} \mathbf{2 e}=85$ : 15$)$. This result indicates that the gold catalyst was particularly effective in promoting the cyclisation step of the coupling reaction. While gold catalysts have been successfully utilised in $\mathrm{C}-\mathrm{H}$ bond activation reactions, ${ }^{6}$ the synergistic effect of Ru/Au catalysts is not entirely clear at the present time.

The formation of both $1: 1$ and $1: 2$ products suggested that product $\mathbf{1}$ is resulted from the cyclisation of 1 : 2 coupling product 2 . To gain further mechanistic insights, the reaction mixture of $\mathbf{1 e}$ and $\mathbf{2 e}$ (1: 1) was periodically monitored by ${ }^{1} \mathrm{H}$ NMR at room temperature, after it had been heated at $95{ }^{\circ} \mathrm{C}$ in the presence of $\mathrm{Ru}_{3}(\mathrm{CO})_{12} / \mathrm{NH}_{4} \mathrm{PF}_{6}$ (10 mol\% Ru) in $\mathrm{C}_{6} \mathrm{D}_{6}$ (Fig. 1). Over time, the peaks due to $\mathbf{1 e}$ at $\delta$ 6.19 , as well as the $\mathrm{NH}$ peak at $\delta 6.24$, increased at the expense of the peaks due to $\mathbf{2 e}\left(\delta 5.27\right.$ and $\left.5.53\left(\mathrm{CQCH}_{2}\right)\right)$. The rate constant, $k_{\mathrm{obs}}=2.1 \times 10^{-2} \mathrm{~h}^{-1}$, of the appearance of $1 \mathrm{e}$ was estimated from a pseudo first-order plot.

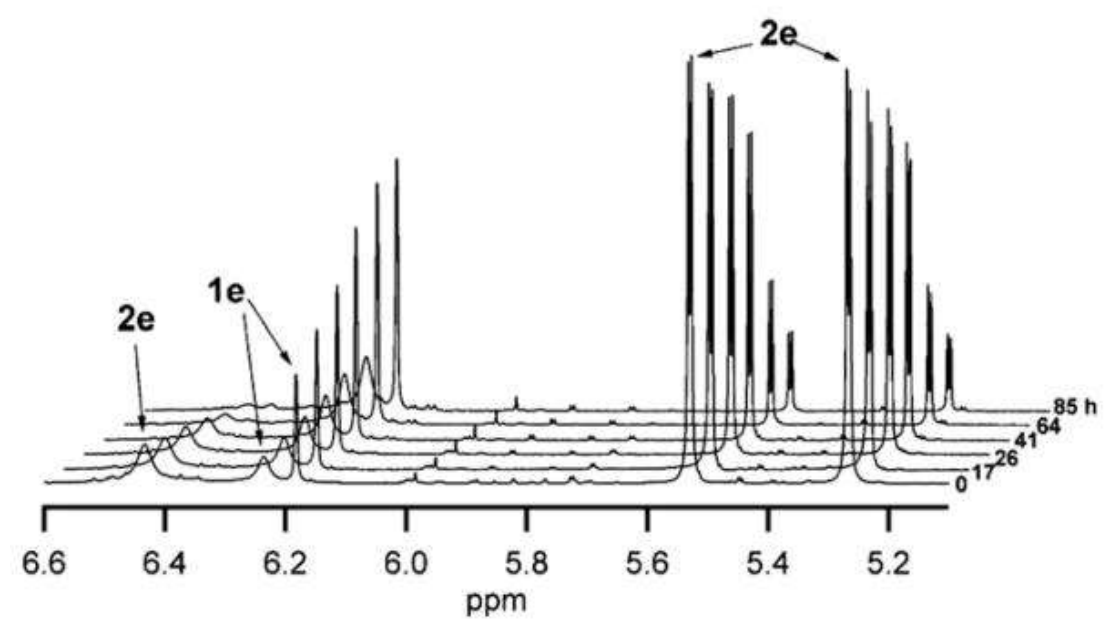

Fig. 1 Partial ${ }^{1} \mathrm{H}$ NMR spectra of the reaction mixture of $\mathbf{1 e}$ and $\mathbf{2 e}$. 
The coupling reaction of 1,2,5-trimethylpyrrole with deuteriumlabelled 4-ethynylanisole- $d_{1}$ ( 2 equiv., $>99 \% \mathrm{D}$ ) in the presence of $\mathrm{Ru}_{3}(\mathrm{CO})_{12} / \mathrm{NH}_{4} \mathrm{PF}_{6}(10 \mathrm{~mol} \% \mathrm{Ru})$ in $\mathrm{C}_{6} \mathrm{D}_{6}$ was monitored by NMR. After $1 \mathrm{~h}$ of heating at $95{ }^{\circ} \mathrm{C}$, the ${ }^{1} \mathrm{H}$ NMR spectrum showed that nearly $15 \%$ of the deuterium from 4-ethynylanisole had exchanged with $35 \%$ of the $\beta$-vinyl hydrogens of the unreacted 1,2,5-trimethylpyrrole, prior to the formation of the coupling products. The product, $\mathbf{2 a}-d$, isolated from a preparative scale reaction of 2,5-dimethylpyrrole with 2 equivalesnts of 4-ethynylanisole- $d_{1}$, contained deuterium at both the a-methyl (33\%) and vinyl (37\%) positions. Also, in support of rapid $\mathrm{H} / \mathrm{D}$ exchange between the two substrates, a relatively small deuterium isotope effect was observed from a separate reaction of 1,2,5-trimethylpyrrole with phenylacetylene/ phenylacetylene- $d_{1}$ when forming 1: 1 coupling product $3 \mathbf{3 e}$. The pseudo first-order plots for the reactions gave $k_{\mathrm{obs}}=1.65 \times 10^{-2}$ and $1.38 \times 10^{-2} \mathrm{~h}^{-1}$ from phenylacetylene and phenylacetylene- $d_{1}$, respectively, which translated into $k_{\mathrm{CH}} / k_{\mathrm{CD}}=1.2$.

These results suggest a mechanism involving sequential alkyne insertion and cyclisation steps, as outlined in Scheme 1. The sequential $\mathrm{C}-\mathrm{H}$ activation and regioselective insertion of alkynes would be mediated by an electrophilic ruthenium catalyst to form 1: 2 coupling product $\mathbf{2}$. The subsequent ruthenium-mediated vinyl $\mathrm{C}-\mathrm{H}$ bond activation and cyclisation steps could be facilitated by coordination of the adjacent olefin to ruthenium via the formation of alkene-hydride species 4 . Cyclisation and reductive elimination would give product $\mathbf{1}$.

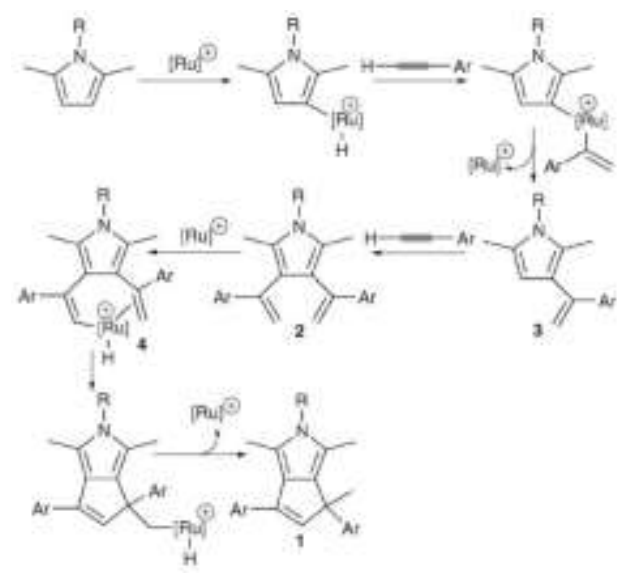

Scheme 1 A possible mechanistic pathway. permission has been granted for this version to appear in e-Publications@Marquette. Royal Society of Chemistry does not grant permission for this article to be further copied/distributed or hosted elsewhere without the express permission from Royal Society of Chemistry. 
In summary, the catalytic formation of bicyclic pyrroles has been achieved from the direct coupling reaction of 2,5-di-methylpyrroles with terminal alkynes. The cyclisation reaction involved three consecutive $\mathrm{sp}^{2} \mathrm{C}-\mathrm{H}$ bond activation and insertion steps.

\section{Supplementary Information}

\section{Experimental details}

General information. All operations were carried out in an inertatmosphere glove box or by using standard high vacuum and Schlenk techniques. Tetrahydrofuran, benzene, hexanes were distilled from purple solutions of sodium and benzophenone immediately prior to use. $\mathrm{CH}_{2} \mathrm{Cl}_{2}$ was distilled from $\mathrm{CaH}_{2}$. The $\mathrm{NMR}$ solvents were dried from activated molecular sieves ( $4 \AA$ ). Pyrrole and alkyne substrates were received from commercial sources and used without further purification. The ${ }^{1} \mathrm{H},{ }^{2} \mathrm{H}$ and ${ }^{13} \mathrm{C}$ NMR spectra were recorded on a Varian Mercury $300 \mathrm{MHz}$ or $400 \mathrm{MHz}$ FT-NMR spectrometer. Mass spectra were recorded from a Hewlett-Packard HP5970 GC/MS spectrometer. Elemental analyses were performed at the Midwest Microlab, Indianapolis, Indiana, USA.

Typical procedure of the catalytic reaction. In a glove box, $\mathrm{Ru}_{3}(\mathrm{CO})_{12}(0.03 \mathrm{mmol}), \mathrm{NH}_{4} \mathrm{PF}_{6}(0.1 \mathrm{mmol}), 2,5$-dimethylpyrrole $(1.0$ $\mathrm{mmol})$ and an alkyne $(2.0 \mathrm{mmol})$ were dissolved in $5 \mathrm{~mL}$ benzene solution in a medium-walled $25 \mathrm{~mL}$ Schlenk tube equipped with teflon stopcock and a magnetic stirring bar. The tube was sealed and was brought out of the box. The reaction tube was heated in an oil bath at $95^{\circ} \mathrm{C}$ for $36-48 \mathrm{~h}$. The tube was opened to air at room temperature, and the crude product mixture was analysed by GC/MS. The solvent was removed under a rotary evaporator, and the organic product was isolated by a column chromatography on silica gel (hexane $/ \mathrm{CH}_{2} \mathrm{Cl}_{2}$ ) under nitrogen. For the combined catalyst system: 2,5-dimethylpyrrole $(1.0 \mathrm{mmol})$, phenylacetylene $(2.0 \mathrm{mmol}), \mathrm{Ru}_{3}(\mathrm{CO})_{12}(0.03 \mathrm{mmol})$, $\mathrm{NH}_{4} \mathrm{PF}_{6}(0.1 \mathrm{mmol}), \mathrm{Au}\left(\mathrm{PPh}_{3}\right) \mathrm{Cl}(0.05 \mathrm{mmol})$ and AgOTf $(0.05 \mathrm{mmol})$ were used under otherwise same reaction conditions.

For 1a: $\delta_{H}\left(300 \mathrm{MHz} ; \mathrm{C}_{6} \mathrm{D}_{6}\right) 7.60-6.83(8 \mathrm{H}, \mathrm{m}, \mathrm{Ar}), 6.25(1 \mathrm{H}$, br s, NH), $6.13(1 \mathrm{H}, \mathrm{s}, \mathrm{C}=\mathrm{CH}), 3.33\left(3 \mathrm{H}, \mathrm{s}, \mathrm{OCH}_{3}\right), 3.32(3 \mathrm{H}, \mathrm{s}$, $\left.\mathrm{OCH}_{3}\right), 2.10\left(3 \mathrm{H}, \mathrm{s}, \mathrm{CH}_{3}\right), 1.92\left(3 \mathrm{H}, \mathrm{s}, \mathrm{CH}_{3}\right), 1.87\left(3 \mathrm{H}, \mathrm{s}, \mathrm{CH}_{3}\right)$; 
$\delta_{\mathrm{C}}\left(75 \mathrm{MHz}, \mathrm{C}_{6} \mathrm{D}_{6}\right) 159.6,158.5,141.1,138.6,138.1,135.4,130.2$, $129.2,127.8,127.4,117.2,114.2,114.1,114.0,54.8\left(\mathrm{OCH}_{3}\right), 54.7$ $\left(\mathrm{OCH}_{3}\right), 50.3\left(\mathrm{CCH}_{3}\right), 24.7\left(\mathrm{CH}_{3}\right), 13.0\left(\mathrm{CH}_{3}\right), 11.8\left(\mathrm{CH}_{3}\right) ; \mathrm{m} / z(\mathrm{GC}-$ MS) $359(\mathrm{M}+)$; Found: $\mathrm{C}, 79.62 ; \mathrm{H}, 7.34 ; \mathrm{N}, 3.25$. Calc. for $\mathrm{C}_{24} \mathrm{H}_{25} \mathrm{NO}_{2}$ : C, 80.19; H, 7.01; N, 3.90\%.

For 1b: $\delta_{H}\left(400 \mathrm{MHz} ; \mathrm{C}_{6} \mathrm{D}_{6}\right)$ 7.58-7.03 $(8 \mathrm{H}, \mathrm{m}, \mathrm{Ar}), 6.20(1 \mathrm{H}$, br s, NH), $6.17(1 \mathrm{H}, \mathrm{s}, \mathrm{C}=\mathrm{CH}), 2.15\left(6 \mathrm{H}, \mathrm{s}, \mathrm{CH}_{3}\right), 2.08\left(3 \mathrm{H}, \mathrm{s}, \mathrm{CH}_{3}\right)$, $1.90\left(3 \mathrm{H}, \mathrm{s}, \mathrm{CH}_{3}\right), 1.86\left(3 \mathrm{H}, \mathrm{s}, \mathrm{CH}_{3}\right) ; \delta_{\mathrm{c}}\left(75 \mathrm{MHz}, \mathrm{C}_{6} \mathrm{D}_{6}\right)$ 142.9, 141.4, $138.9,136.6,135.1,135.0,134.7,129.1,127.9,126.7,117.0,114.1$, $50.6\left(\mathrm{CCH}_{3}\right), 24.3\left(\mathrm{CH}_{3}\right), 21.1\left(\mathrm{CH}_{3}\right), 20.9\left(\mathrm{CH}_{3}\right), 12.8\left(\mathrm{CH}_{3}\right), 11.6$ $\left(\mathrm{CH}_{3}\right) ; \mathrm{m} / \mathrm{z}$ (GC-MS) $327(\mathrm{M}+)$; Found: $\mathrm{C}, 88.02 ; \mathrm{H}, 7.62 ; \mathrm{N}, 4.31$. Calc. for $\mathrm{C}_{24} \mathrm{H}_{25} \mathrm{~N}$ : C, 88.03; $\mathrm{H}, 7.70 ; \mathrm{N}, 4.28 \%$.

For 1c: $\delta_{H}\left(400 \mathrm{MHz} ; \mathrm{C}_{6} \mathrm{D}_{6}\right) 7.61-6.85(8 \mathrm{H}, \mathrm{m}, \mathrm{Ar}), 6.12(1 \mathrm{H}, \mathrm{s}$, $\mathrm{C}=\mathrm{CH}), 3.34\left(6 \mathrm{H}, \mathrm{s}, \mathrm{OCH}_{3}\right), 2.74\left(3 \mathrm{H}, \mathrm{s}, \mathrm{NCH}_{3}\right), 2.12\left(3 \mathrm{H}, \mathrm{s}, \mathrm{CH}_{3}\right)$, $1.94\left(3 \mathrm{H}, \mathrm{s}, \mathrm{CH}_{3}\right), 1.90\left(3 \mathrm{H}, \mathrm{s}, \mathrm{CH}_{3}\right) ; \delta_{\mathrm{C}}\left(100 \mathrm{MHz}, \mathrm{C}_{6} \mathrm{D}_{6}\right)$ 159.4, $158.3,140.9,138.7,138.0,134.6,130.3,129.2,127.7,126.4,119.2$, $116.2,113.9,113.8,54.7\left(\mathrm{OCH}_{3}\right), 54.6\left(\mathrm{OCH}_{3}\right), 50.5\left(\mathrm{CCH}_{3}\right), 29.4$ $\left(\mathrm{NCH}_{3}\right), 24.6(\mathrm{CH} 3), 11.7\left(\mathrm{CH}_{3}\right), 11.0\left(\mathrm{CH}_{3}\right) ; \mathrm{m} / \mathrm{z}(\mathrm{GC}-\mathrm{MS}) 373(\mathrm{M}+)$; Found: $\mathrm{C}, 79.87 ; \mathrm{H}, 7.16 ; \mathrm{N}, 3.68$. Calc. for $\mathrm{C}_{25} \mathrm{H}_{27} \mathrm{NO}_{2}$ : C, 80.40; $\mathrm{H}$, $7.29 ; \mathrm{N}, 3.75 \%$.

For 1d: $\delta_{H}\left(300 \mathrm{MHz}\right.$; acetone- $\left.d_{6}\right) 7.42-7.04(8 \mathrm{H}, \mathrm{m}, \mathrm{Ar}), 5.93$ $(1 \mathrm{H}, \mathrm{s}, \mathrm{C}=\mathrm{CH}), 3.39\left(3 \mathrm{H}, \mathrm{s}, \mathrm{NCH}_{3}\right), 2.34\left(3 \mathrm{H}, \mathrm{s}, \mathrm{CH}_{3}\right), 2.26(3 \mathrm{H}, \mathrm{s}$, $\left.\mathrm{CH}_{3}\right), 2.20\left(3 \mathrm{H}, \mathrm{s}, \mathrm{CH}_{3}\right), 2.08\left(3 \mathrm{H}, \mathrm{s}, \mathrm{CH}_{3}\right), 1.67\left(3 \mathrm{H}, \mathrm{s}, \mathrm{CH}_{3}\right) ; \delta_{\mathrm{c}}(75$ $\mathrm{MHz}$; acetone- $\left.d_{6}\right) 143.4,141.0,139.6,137.4,135.5,135.2,134.2$, 129.7, 129.5, 128.3, 127.1, 126.3, 120.1, 117.0, $51.2\left(\mathrm{CCH}_{3}\right), 30.2$ $\left(\mathrm{NCH}_{3}\right), 24.8\left(\mathrm{CH}_{3}\right), 21.2\left(\mathrm{CH}_{3}\right), 20.9\left(\mathrm{CH}_{3}\right), 11.8\left(\mathrm{CH}_{3}\right), 11.2\left(\mathrm{CH}_{3}\right)$; $\mathrm{m} / \mathrm{z}$ (GC-MS) $341(\mathrm{M}+)$; Found: C, 88.08; H, 8.03; N, 4.02. Calc. for $\mathrm{C}_{25} \mathrm{H}_{27} \mathrm{~N}:$ C, 87.93; $\mathrm{H}, 7.97 ; \mathrm{N}, 4.10 \%$.

For 1e: $\delta_{H}\left(400 \mathrm{MHz} ; \mathrm{C}_{6} \mathrm{D}_{6}\right) 7.68-7.01(10 \mathrm{H}, \mathrm{m}, \mathrm{Ar}), 6.24(1 \mathrm{H}$, br s, NH), $6.19(1 \mathrm{H}, \mathrm{s}, \mathrm{C}=\mathrm{CH}), 2.10\left(3 \mathrm{H}, \mathrm{s}, \mathrm{CH}_{3}\right), 1.92\left(3 \mathrm{H}, \mathrm{s}, \mathrm{CH}_{3}\right)$, $1.89\left(3 \mathrm{H}, \mathrm{s}, \mathrm{CH}_{3}\right) ; \delta_{\mathrm{C}}\left(100 \mathrm{MHz} \mathrm{C}_{6} \mathrm{D}_{6}\right)$ 145.8, 139.3, 137.5, 134.9, $128.5,128.4,127.4,127.0,126.1,121.2,117.3,114.3,51.0\left(\mathrm{CCH}_{3}\right)$, $24.3\left(\mathrm{CH}_{3}\right), 12.9\left(\mathrm{CH}_{3}\right), 11.7\left(\mathrm{CH}_{3}\right) ; m / z(\mathrm{GC}-\mathrm{MS}) 299(\mathrm{M}+)$.

For 2e: $\delta_{H}\left(400 \mathrm{MHz} ; \mathrm{C}_{6} \mathrm{D}_{6}\right) 7.68-7.01(10 \mathrm{H}, \mathrm{m}, \mathrm{Ar}), 6.44(1 \mathrm{H}$, br s, NH), $5.53(2 \mathrm{H}, \mathrm{d}, \mathrm{J}=1.6 \mathrm{~Hz}, \mathrm{C}=\mathrm{CH} H), 5.27(2 \mathrm{H}, \mathrm{d}, \mathrm{J}=1.6 \mathrm{~Hz}$, 
$\mathrm{C}=\mathrm{CHH}), 1.92\left(6 \mathrm{H}, \mathrm{s}, \mathrm{CH}_{3}\right) ; \delta_{\mathrm{C}}\left(100 \mathrm{MHz}, \mathrm{C}_{6} \mathrm{D}_{6}\right) 144.4,142.9,141.8$, $128.0,127.6,127.2,126.8,123.6,114.4,12.0\left(\mathrm{CH}_{3}\right) ; m / z$ (GC-MS) $299(M+)$.

For 2f: $\delta_{H}\left(300 \mathrm{MHz} ; \mathrm{C}_{6} \mathrm{D}_{6}\right)$ 7.17-6.95 $(8 \mathrm{H}, \mathrm{m}, \mathrm{Ar}), 6.25(1 \mathrm{H}, \mathrm{br}$ $\mathrm{s}, \mathrm{NH}), 5.40(2 \mathrm{H}, \mathrm{d}, \mathrm{J}=2.4 \mathrm{~Hz}, \mathrm{C}=\mathrm{CH} H), 5.16(2 \mathrm{H}, \mathrm{d}, \mathrm{J}=2.4 \mathrm{~Hz}$, $\mathrm{C}=\mathrm{CHH}), 2.07\left(6 \mathrm{H}, \mathrm{s}, \mathrm{CH}_{3}\right), 1.69\left(6 \mathrm{H}, \mathrm{s}, \mathrm{CH}_{3}\right) ; \delta \mathrm{H}(400 \mathrm{MHz}$; acetone$\left.d_{6}\right) 9.58(1 \mathrm{H}$, br s, NH$), 7.05-6.94(8 \mathrm{H}, \mathrm{m}, \mathrm{Ar}), 5.21(2 \mathrm{H}, \mathrm{d}, \mathrm{J}=2.7$ $\mathrm{Hz}, \mathrm{C}=\mathrm{CH} H), 5.98(2 \mathrm{H}, \mathrm{d}, \mathrm{J}=2.7 \mathrm{~Hz}, \mathrm{C}=\mathrm{CHH}), 1.99\left(6 \mathrm{H}, \mathrm{s}, \mathrm{CH}_{3}\right)$, $1.92\left(6 \mathrm{H}, \mathrm{s}, \mathrm{CH}_{3}\right)$; $\delta_{\mathrm{C}}\left(75 \mathrm{MHz}_{1} \mathrm{C}_{6} \mathrm{D}_{6}\right) 144.5,143.2,135.8,130.6$, $130.4,126.9,125.4,123.4,121.3,117.0(\mathrm{C}=\mathrm{CH} 2), 20.6\left(\mathrm{CH}_{3}\right), 11.9$ $\left(\mathrm{CH}_{3}\right) ; \delta_{c}\left(100 \mathrm{MHz}\right.$; acetone- $\left.d_{6}\right) 145.6,143.9,136.4,130.0,130.9$, $127.4,125.9,124.6,121.3,116.6\left(\mathrm{C}=\mathrm{CH}_{2}\right), 20.7\left(\mathrm{CH}_{3}\right), 12.0\left(\mathrm{CH}_{3}\right)$; $\mathrm{m} / \mathrm{z}$ (GC-MS) $327(\mathrm{M}+)$; Found $\mathrm{C}, 87.26 ; \mathrm{H}, 7.70 ; \mathrm{N}, 4.32$. Calc. for $\mathrm{C}_{24} \mathrm{H}_{25} \mathrm{~N}: \mathrm{C}, 88.03 ; \mathrm{H}, 7.70 ; \mathrm{N}, 4.28 \%$.

For 3f: $\delta_{H}\left(300 \mathrm{MHz} ; \mathrm{C}_{6} \mathrm{D}_{6}\right) 7.41-7.11(4 \mathrm{H}, \mathrm{m}, \mathrm{Ar}), 6.25(1 \mathrm{H}, \mathrm{br}$ $\mathrm{s}, \mathrm{NH}), 5.91(1 \mathrm{H}, \mathrm{s}, \mathrm{C}=\mathrm{CH}), 5.51(1 \mathrm{H}, \mathrm{d}, \mathrm{J}=1.8 \mathrm{~Hz}, \mathrm{C}=\mathrm{CH} H), 5.05$ (1 $\mathrm{H}, \mathrm{d}, \mathrm{J}=1.8 \mathrm{~Hz}, \mathrm{C}=\mathrm{CHH}), 2.27\left(3 \mathrm{H}, \mathrm{s}, \mathrm{CH}_{3}\right), 1.81\left(3 \mathrm{H}, \mathrm{s}, \mathrm{CH}_{3}\right), 1.64$ $\left(3 \mathrm{H}, \mathrm{s}, \mathrm{CH}_{3}\right) ; \delta_{\mathrm{C}}\left(75 \mathrm{MHz}, \mathrm{C}_{6} \mathrm{D}_{6}\right) 145.9,144.3,136.1,130.1,129.8$, $125.9,124.6,123.3,121.0,20.1\left(\mathrm{CH}_{3}\right), 12.7\left(\mathrm{CH}_{3}\right), 12.6\left(\mathrm{CH}_{3}\right) ; \mathrm{m} / z$ (GC-MS) $211(\mathrm{M}+)$. 
NOT THE PUBLISHED VERSION; this is the author's final, peer-reviewed manuscript. The published version may be accessed by following the link in the citation at the bottom of the page.

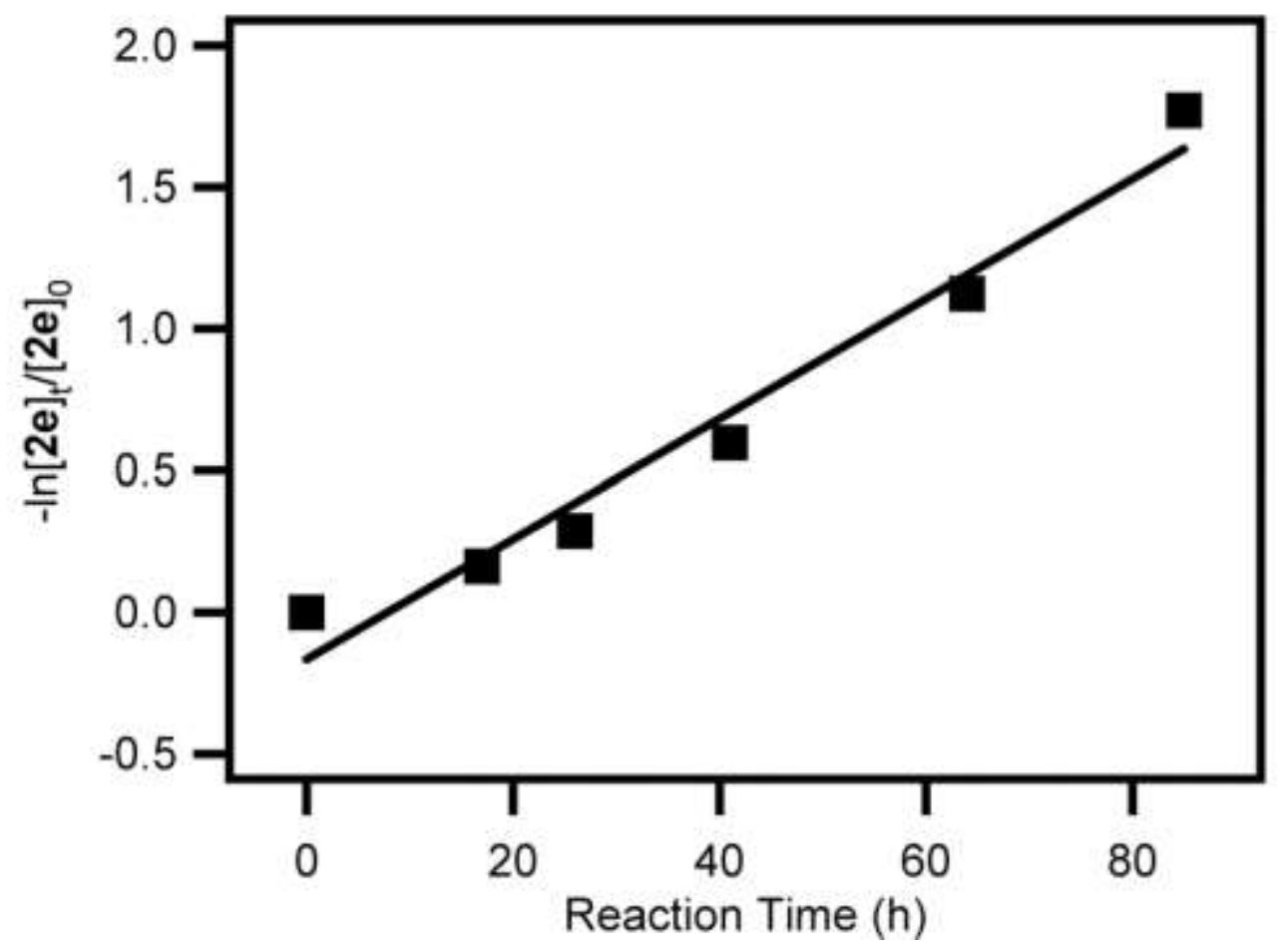

Chemical Communications, Vol. 20, (May 2008): pg. 2349-2351. DOI. This article is (C) Royal Society of Chemistry and permission has been granted for this version to appear in e-Publications@Marquette. Royal Society of Chemistry does not grant permission for this article to be further copied/distributed or hosted elsewhere without the express permission from Royal Society of Chemistry. 
NOT THE PUBLISHED VERSION; this is the author's final, peer-reviewed manuscript. The published version may be accessed by following the link in the citation at the bottom of the page.

\section{${ }^{1} \mathrm{H}$ and ${ }^{13} \mathrm{C}\left\{{ }^{1} \mathrm{H}\right\}$ NMR of $1 \mathrm{a}$ in $\mathrm{C}_{6} \mathrm{D}_{6}$}
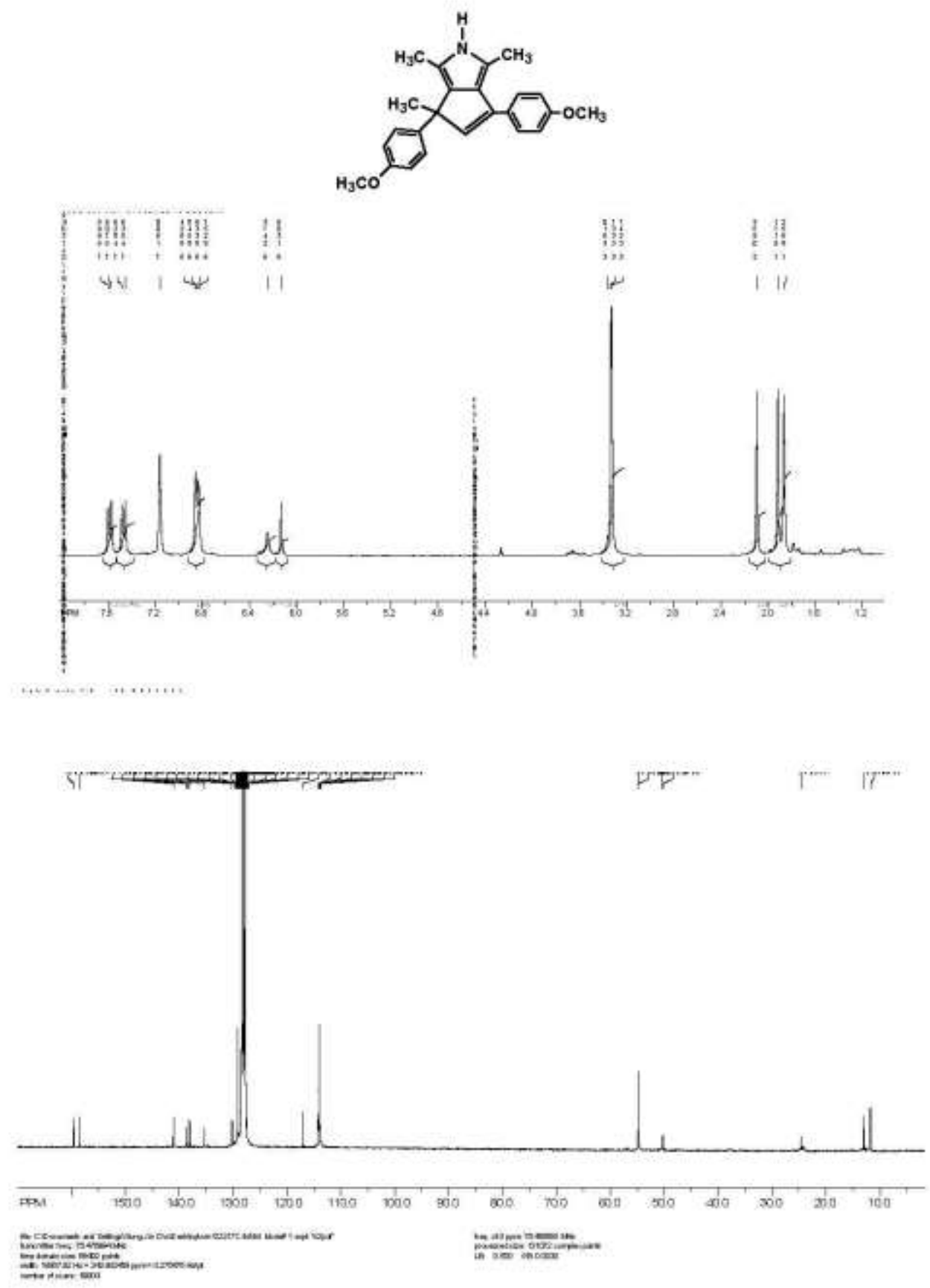

Chemical Communications, Vol. 20, (May 2008): pg. 2349-2351. DOI. This article is (C) Royal Society of Chemistry and permission has been granted for this version to appear in e-Publications@Marquette. Royal Society of Chemistry does not grant permission for this article to be further copied/distributed or hosted elsewhere without the express permission from Royal Society of Chemistry. 
NOT THE PUBLISHED VERSION; this is the author's final, peer-reviewed manuscript. The published version may be accessed by following the link in the citation at the bottom of the page.

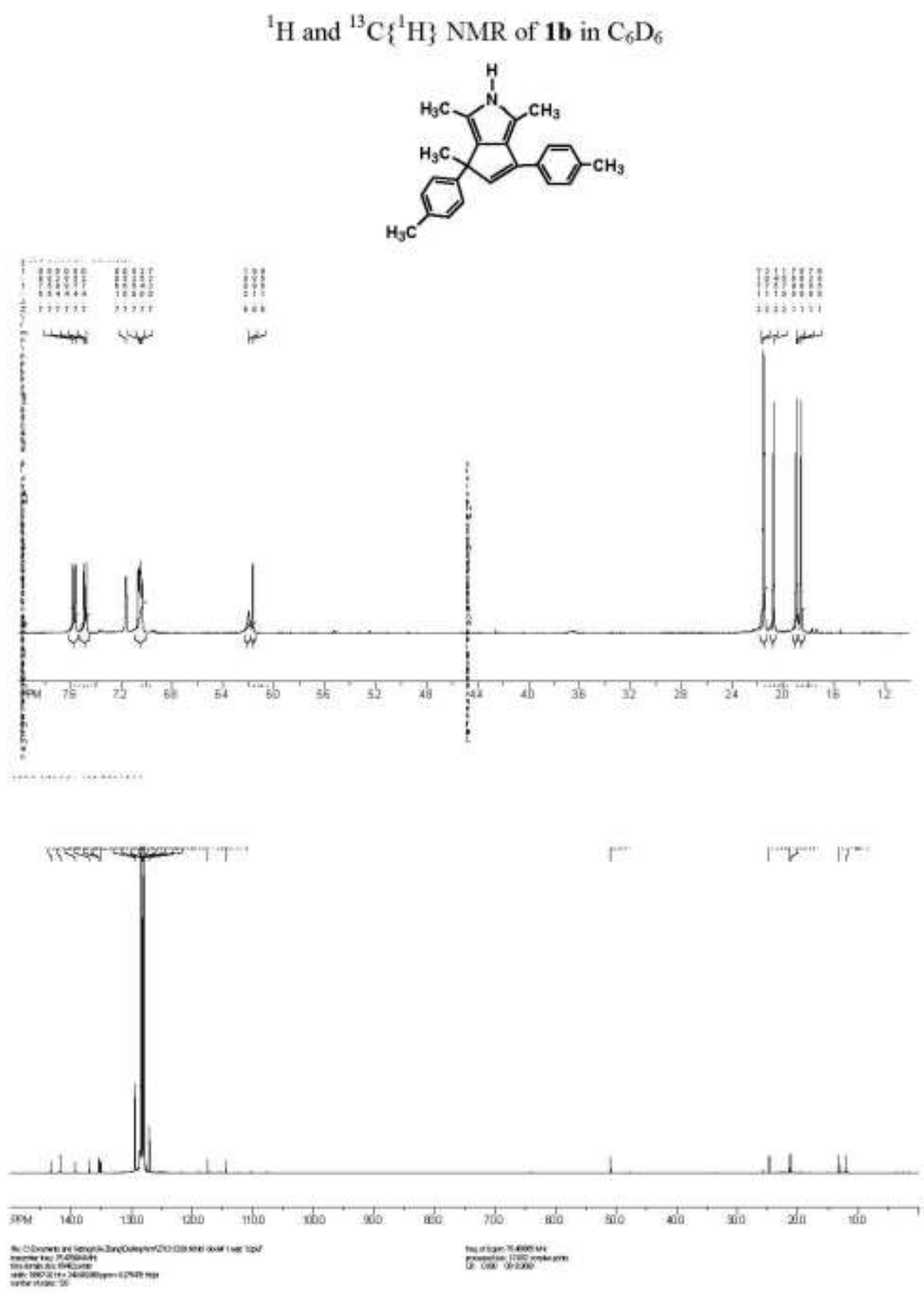

Chemical Communications, Vol. 20, (May 2008): pg. 2349-2351. DOI. This article is @ Royal Society of Chemistry and permission has been granted for this version to appear in e-Publications@Marquette. Royal Society of Chemistry does not grant permission for this article to be further copied/distributed or hosted elsewhere without the express permission from Royal Society of Chemistry. 
NOT THE PUBLISHED VERSION; this is the author's final, peer-reviewed manuscript. The published version may be accessed by following the link in the citation at the bottom of the page.

${ }^{1} \mathrm{H}$ and ${ }^{13} \mathrm{C}\left\{{ }^{1} \mathrm{H}\right\}$ NMR of $1 \mathrm{c}$ in $\mathrm{C}_{6} \mathrm{D}_{6}$<smiles>COc1ccc(C=CC2=C(C)C(C)(C)C(C)=C2c2ccc(OC)cc2)cc1</smiles>
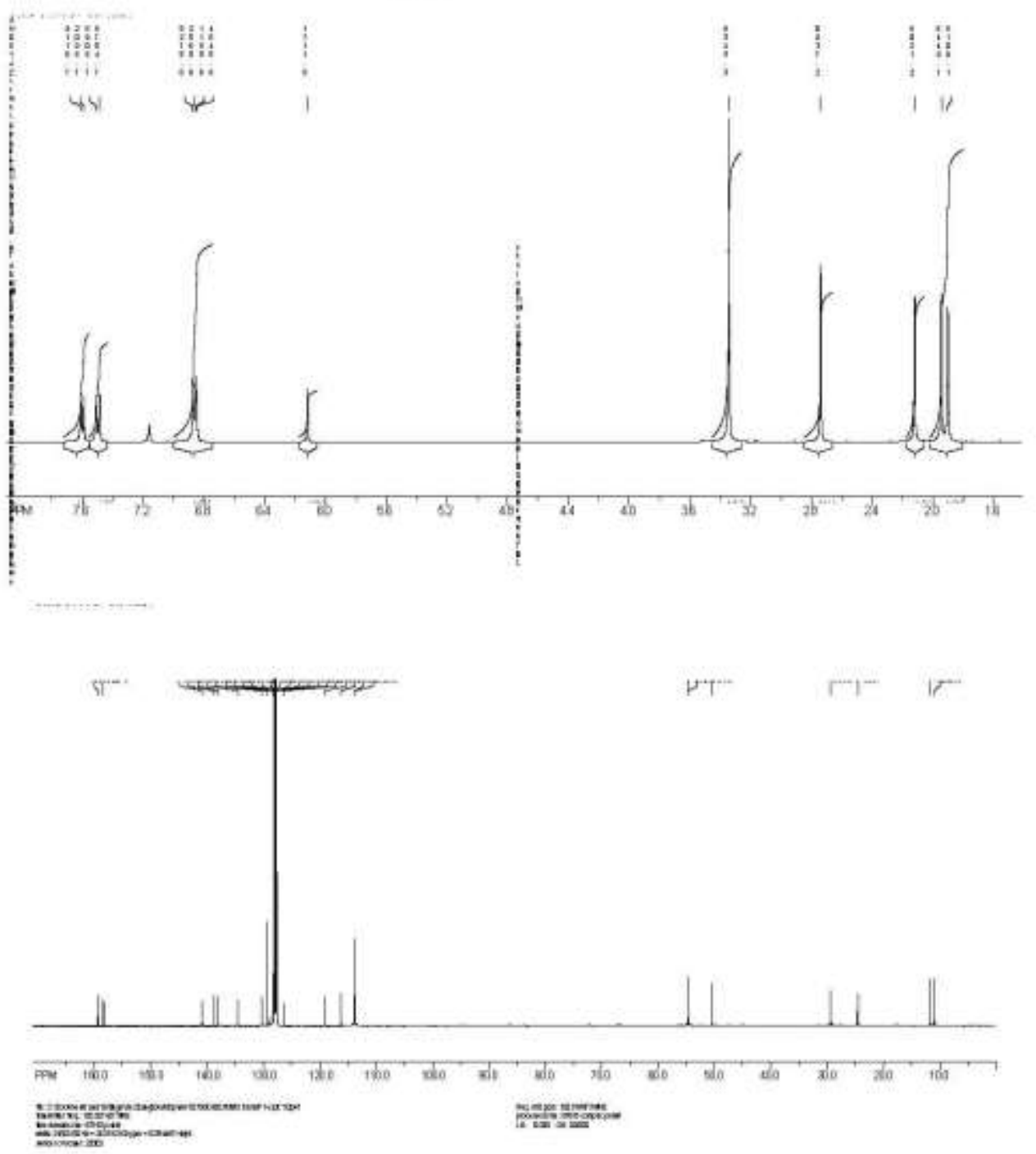

Chemical Communications, Vol. 20, (May 2008): pg. 2349-2351. DOI. This article is @ Royal Society of Chemistry and permission has been granted for this version to appear in e-Publications@Marquette. Royal Society of Chemistry does not grant permission for this article to be further copied/distributed or hosted elsewhere without the express permission from Royal Society of Chemistry. 
NOT THE PUBLISHED VERSION; this is the author's final, peer-reviewed manuscript. The published version may be accessed by following the link in the citation at the bottom of the page.

$\left.{ }^{13} \mathrm{C}_{\{}{ }^{1} \mathrm{H}\right\}$ NMR of $2 \mathrm{f}$ in $\mathrm{C}_{6} \mathrm{D}_{6}$

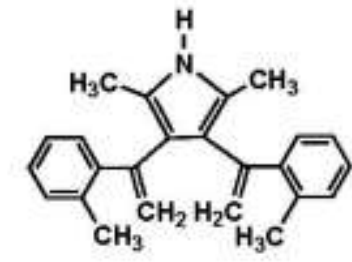

$(+n+\cdots+\cdots+\cdots+\cdots$

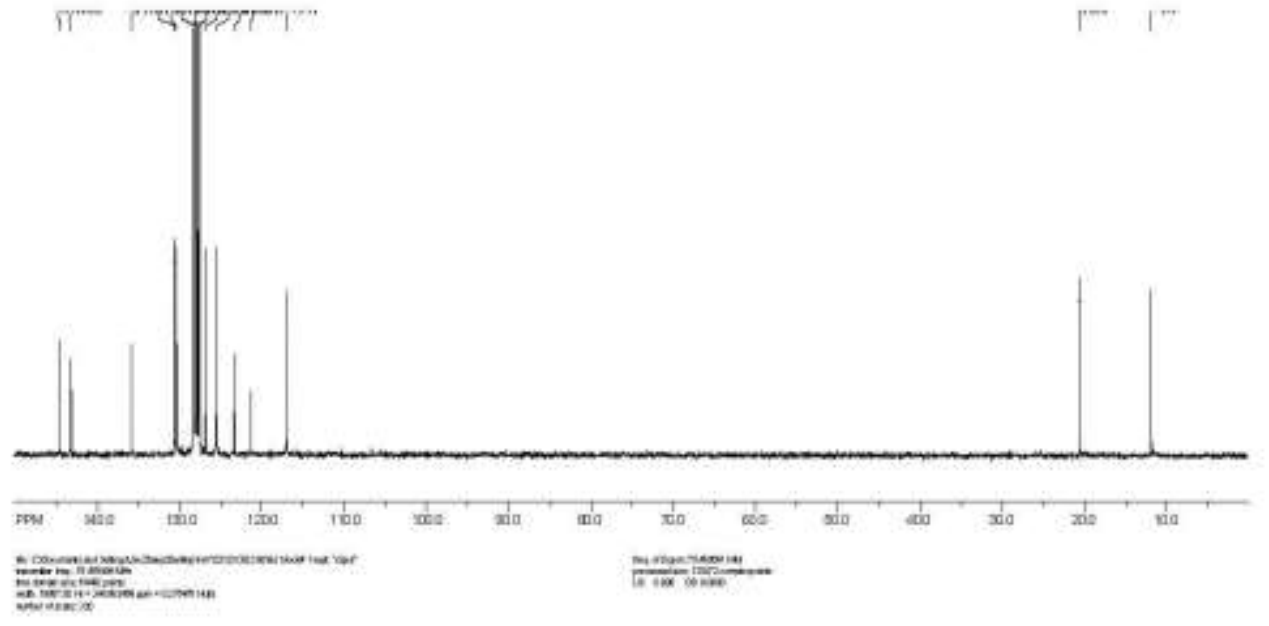

Chemical Communications, Vol. 20, (May 2008): pg. 2349-2351. DOI. This article is (C) Royal Society of Chemistry and permission has been granted for this version to appear in e-Publications@Marquette. Royal Society of Chemistry does not grant permission for this article to be further copied/distributed or hosted elsewhere without the express permission from Royal Society of Chemistry. 
NOT THE PUBLISHED VERSION; this is the author's final, peer-reviewed manuscript. The published version may be accessed by following the link in the citation at the bottom of the page.

\section{${ }^{1} \mathrm{H}$ and ${ }^{13} \mathrm{C}\left\{{ }^{1} \mathrm{H}\right\}$ NMR of $\mathbf{3 f}$ in $\mathrm{C}_{6} \mathrm{D}_{6}$}<smiles>C=C(c1ccccc1C)c1cc(C)[nH]c1C</smiles>
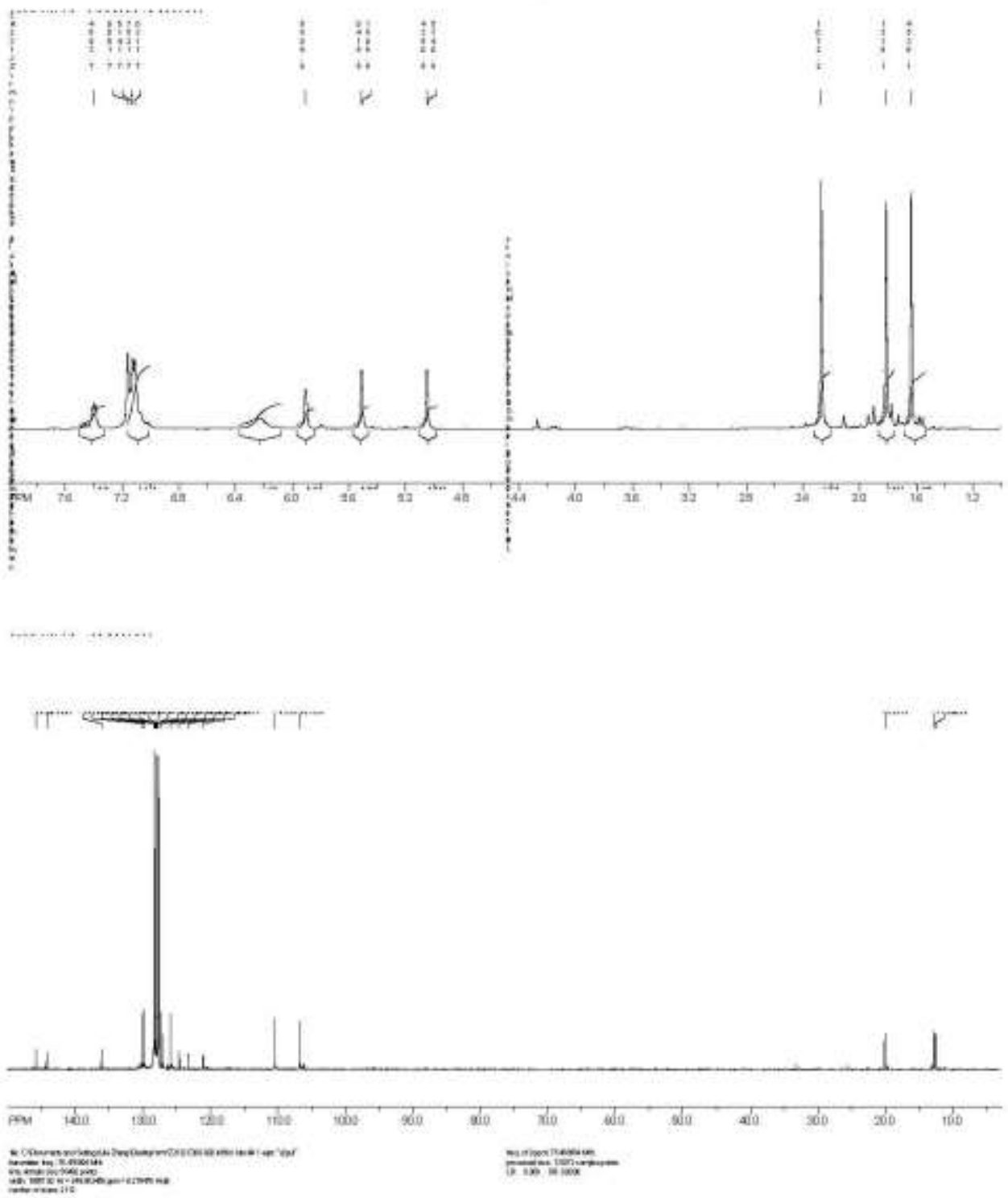

Chemical Communications, Vol. 20, (May 2008): pg. 2349-2351. DOI. This article is (C) Royal Society of Chemistry and permission has been granted for this version to appear in e-Publications@Marquette. Royal Society of Chemistry does not grant permission for this article to be further copied/distributed or hosted elsewhere without the express permission from Royal Society of Chemistry. 
NOT THE PUBLISHED VERSION; this is the author's final, peer-reviewed manuscript. The published version may be accessed by following the link in the citation at the bottom of the page.

Acknowledgments: Financial support from the US National Institute of Health General Medical Sciences (R15 GM55987) is gratefully acknowledged.

Footnotes: ${ }^{\dagger}$ Electronic supplementary information (ESI) available: The experimental procedure and characterization data of organic products. See DOI: $10.1039 / b 804263 b$

${ }^{\ddagger}$ Representative experimental procedure: In a glove box, $\mathrm{Ru}_{3}(\mathrm{CO})_{12}(0.03$ $\mathrm{mmol}), \mathrm{NH}_{4} \mathrm{PF}_{6}(0.1 \mathrm{mmol}), 2,5$-dimethylpyrrole $(1.0 \mathrm{mmol})$ and an alkyne $(2.0 \mathrm{mmol})$ were dissolved in benzene $(5 \mathrm{~mL})$ in a medium-walled $25 \mathrm{~mL}$ Schlenk tube, equipped with a Teflon stopcock and a magnetic stirring bar. The reaction tube was sealed, brought out of the box and heated in an oil bath at $95^{\circ} \mathrm{C}$ for $36-48 \mathrm{~h}$. The tube was opened to air at room temperature and the crude product mixture analysed by GC. The solvent was removed using a rotary evaporator and the organic product was isolated by column chromatography on silica gel (hexane $/ \mathrm{CH}_{2} \mathrm{Cl}_{2}$ ) under a nitrogen atmosphere.

For 1b: $\delta_{\mathrm{H}}\left(400 \mathrm{MHz} ; \mathrm{C}_{6} \mathrm{D}_{6}\right) 7.58-7.03(8 \mathrm{H}, \mathrm{m}, \mathrm{Ar}), 6.20(1 \mathrm{H}, \mathrm{br} \mathrm{s}$, $\mathrm{NH}), 6.17(1 \mathrm{H}, \mathrm{s}, \mathrm{CQCH}), 2.15\left(6 \mathrm{H}, \mathrm{s}, \mathrm{CH}_{3}\right), 2.08\left(3 \mathrm{H}, \mathrm{s}, \mathrm{CH}_{3}\right), 1.90$ $\left(3 \mathrm{H}, \mathrm{s}, \mathrm{CH}_{3}\right)$ and $1.86\left(3 \mathrm{H}, \mathrm{s}, \mathrm{CH}_{3}\right) ; \delta_{\mathrm{C}}\left(75 \mathrm{MHz} ; \mathrm{C}_{6} \mathrm{D}_{6}\right) 142.9,141.4$, $138.9,136.6,135.1,135.0,134.7,129.1,127.9,126.7,117.0,114.1$, $50.6\left(\mathrm{CCH}_{3}\right), 24.3\left(\mathrm{CH}_{3}\right), 21.1\left(\mathrm{CH}_{3}\right), 20.9\left(\mathrm{CH}_{3}\right), 12.8\left(\mathrm{CH}_{3}\right)$ and 11.6 $\left(\mathrm{CH}_{3}\right) ; \mathrm{m} / \mathrm{z}(\mathrm{GC}-\mathrm{MS}) 327\left(\mathrm{M}^{+}\right)$; Found: $\mathrm{C}, 88.02 ; \mathrm{H}, 7.62 ; \mathrm{N}, 4.31$.

\section{Notes and references}

1. For recent reviews, see: (a) C. Jia, T. Kitamura and Y. Fujiwara, Acc. Chem. Res., 2001, 34, 633; (b) F. Kakiuchi and S. Murai, Acc. Chem. Res., 2002, 35, 826; (c) D. Alberico, M. E. Scott and M. Lautens, Chem. Rev., 2007, 107, 174.

2. Recent selected examples: (a) W. Lu, C. Jia, T. Kitamura and Y. Fujiwara, Org. Lett., 2000, 2, 2927; (b) R. K. Thalji, K. A. Ahrendt, R. G. Bergman and J. A. Ellman, J. Am. Chem. Soc., 2001, 123, 9692; (c) C. Liu, X. Han, X. Wang and R. A. Widenhoefer, J. Am. Chem. Soc., 2004, 126, 3700; (d) X.Wan, Z. Ma, B. Li, K. Zhang, S. Cao, S. Zhang and Z. Shi, J. Am. Chem. Soc., 2006, 128, 7416; (e) X. Chen, C. E. Goodhue and J.-Q. Yu, J. Am. Chem. Soc., 2006, 128, 12634; (f) J. C. Lewis, R. G. Bergman and J. A. Ellman, J. Am. Chem. Soc., 2007, 129, 5332.

3 (a) D. Kalyani, N. R. Deprez, L. V. Desai and M. S. Sanford, J. Am. Chem. Soc., 2005, 127, 7330; (b) H.-Y. Thu, W.-Y. Yu and C.-M. Che, J. Am. Chem. Soc., 2006, 128, 9048; (c) B.-J. Li, S.-L. Tian, Z. Fang and Z.J. Shi, Angew. Chem., Int. Ed., 2008, 47, 1115.

4 E. M. Ferreira and B. M. Stoltz, J. Am. Chem. Soc., 2003, 125, 9578. 
NOT THE PUBLISHED VERSION; this is the author's final, peer-reviewed manuscript. The published version may be accessed by following the link in the citation at the bottom of the page.

5 (a) C. S. Yi, S. Y. Yun and I. A. Guzei, J. Am. Chem. Soc., 2005, 127, 5782;

(b) C. S. Yi and S. Y. Yun, J. Am. Chem. Soc., 2005, 127, 17000.

6 (a) C. Jones, D. Taube, V. R. Ziatdinov, R. A. Periana, R. J. Nielsen, J.

Oxgaard and W. A. Goddard III, Angew. Chem., Int. Ed., 2004, 43, 4626; (b) Z. Li, D. A. Capretto, R. O. Rahaman and C. He, J. Am. Chem. Soc., 2007, 129, 12058.

About the Authors: Department of Chemistry, Marquette University, Milwaukee, Wisconsin, USA. Fax: +1 414-288-7066; Tel: +1 414-288-3536 Corresponding author. Chae S. Yi: chae.yi@marquette.edu 